\title{
Western Mareotis lake(s) during the Late Holocene (4th century BCE-8th century CE): diachronic evolution in the western margin of the Nile Delta and evidence for the digging of a canal complex during the early Roman period
}

\author{
Maël Crépy ${ }^{1}$ and Marie-Françoise Boussac ${ }^{2}$ \\ ${ }^{1}$ UMR5133 Archéorient and UMR5189 HiSoMA, Maison de l'Orient et de la Méditerranée, CNRS, Lyon 69007, France \\ ${ }^{2}$ UMR7041 ArScAn, Université Paris Nanterre, 21 allée de l'Université, 92023 Nanterre, France
}

Correspondence: $\quad$ Maël Crépy (crepy.mc@gmail.com)

Relevant dates: $\quad$ Received: 25 September 2020 - Revised: 7 December 2020 - Accepted: 17 December 2020 Published: 28 January 2021

How to cite:

Crépy, M. and Boussac, M.-F.: Western Mareotis lake(s) during the Late Holocene (4th century BCE8th century CE): diachronic evolution in the western margin of the Nile Delta and evidence for the digging of a canal complex during the early Roman period, E\&G Quaternary Sci. J., 70, 39-52, https://doi.org/10.5194/egqsj-70-39-2021, 2021.

Abstract:

Lake Mareotis (modern Mariut), located near the Mediterranean coast of Egypt west of the Nile Delta, is bordered by ancient sites dating from the New Kingdom (end of the 2nd millennium BCE) to the Medieval period (8th century CE), the most famous one being Alexandria. In its western part (wadi Mariut), several sites are equipped with harbour structures, but they also have structures contemporaneous with them that are not compatible with the lake level required for the operation of the harbour. Between the 1990s and 2010, several sedimentological studies tried to solve this paradox without completely succeeding. To go further, this study is based on the reassessment of geoarchaeological data and on the analysis of early scholars' accounts (1800-1945), maps (1807-1958) and satellite photographs (Corona). It allows us to reconstruct the extension of the lake(s) at different periods in wadi Mariut. During the 1st millennium BCE, the Mariut lagoon experienced a drawdown in its western part, and several distinct lakes formed, followed by building operations in some emerged areas during the Hellenistic period (332-30 BCE). During the early Roman period (30 BCE-284 CE), the digging of several canals in the 2nd century CE to connect the sites of the wadi Mariut to the eastern part of the Mariut basin reconfigured the lake(s).

Kurzfassung: Der Mareotis-See (mod. Mariut), nahe der ägyptischen Mittelmeerküste, westlich des Nildeltas, liegt an antiken Siedlungen, die vom Neuen Reich (Ende des zweiten Jt. v. Chr.) bis ins Mittelalter (8. Jh. n. Chr.) datieren; die berühmteste ist Alexandria. In seinem westlichen Teil (Wadi Mariut) sind mehrere Siedlungen mit Hafenanlagen angelegt, enthalten aber auch zeitgenössische Gebäude, die mit dem Seespiegel unvereinbar sind und die für das Funktionieren der Häfen in Betracht gezogen werden müssen. Zwischen den 1990er Jahren und 2010 wurden mehrere Studien, die sich auf die Sedimentologie stützten, auf diese Frage angewandt, ohne dieses Paradox vollständig zu lösen. Um noch einen Schritt weiter zu gehen, stützt sich diese Studie auf die Neubewertung geoarchäologischer Daten, und 
zwar auf Analyse von Berichten früher Gelehrter (1800-1945), Karten (1807-1958) und Satellitenfotos (Corona). Sie ermöglicht es, die Ausdehnung des Sees/der Seen zu verschiedenen Zeiten im Wadi Mariut zu rekonstruieren. Während des ersten Jt. v. Chr. erlebte die Lagune in ihrem westlichen Teil eine Absenkung, gefolgt von Bauarbeiten in neu entstandenen Gebieten während der hellenistischen Periode (332-30 v. Chr.). Durch das Graben mehrerer Kanäle im 2. Jh. n. Chr., um die Siedlungen mit dem östlichen Teil des Mariut-Beckens zu verbinden, wurden der See bzw. die Seen neu gestaltet.

\section{Introduction and objectives}

Lake Mariut, ancient Mareotis (Fig. 1), is a lagoon that polarised the human occupation of Egypt's north-western margins during antiquity. The region developed mainly after the foundation of Alexandria in 332 BCE (Fraser, 1972), although earlier occupation is archaeologically evidenced since the New Kingdom at Plinthine (Boussac et al., 2015; Boussac and Redon, 2021) and Kom Bahig (Empereur, 2018). Agricultural lands and towns, such as Taposiris on the north shore (Boussac, 2015) and Marea (Pichot, 2012) on the southern one, flourished until the Arab-Muslim conquest, which was followed in the 7-8th centuries CE by a reconfiguration of the territory and the abandonment of many settlements (Décobert, 2002). During all periods, the human occupation of the region has been closely linked to the lake (Blue and Khalil, 2011).

Strabo $(\sim 60 \mathrm{BCE}-\sim 20 \mathrm{CE})$ mentions a very large lake (Strabo, 2015:17, 14) of major economic importance (Strabo, 2015:17, 7). Later, accounts by travellers from the 6th century CE to 1798 (Sennoune, 2015), maps (Awad, 2010) and sedimentological data (Flaux, 2011) indicate significant fluctuations of the lake levels and positions (including phases of desiccation). At the beginning of the French expedition to Egypt (1798-1801), the lake area was dry (Le Père, 1825).

If one focuses on the wadi Mariut (western part of the Mariut basin; Fig. 1), the presence at some Hellenistic and/or Roman sites of harbour structures close to remains that are incompatible with the vicinity of a lake (e.g. amphora workshops) and dating back to the same periods constitutes a geoarchaeological paradox. How can this paradox be solved? Did the lake levels shift at high frequency during this period? Have several independent lakes of small extent coexisted in the Mariut basin? Should a major water engineering work be considered?

This geoarchaeological study, undertaken within the French mission at Taposiris Magna and Plinthine (dir. M.-F. Boussac and then B. Redon), aims to assess, through a composite method, the western extension of the Mareotis lake(s) in wadi Mariut from the 4th century BCE to the 8th century CE.

\section{General settings and previous studies}

\subsection{Geomorphic settings}

Lake Mariut lies at the interface between three geomorphological systems: the Mediterranean littoral, the Nile Delta and the Libyan desert. During the Holocene, distinct morphogenetic processes have influenced its evolution: climate change and the evolution of the Nile floods (Macklin et al., 2015), sea level rise (Dalongeville and Fouache, 2005), wind erosion (Woronko, 2012; Crépy, 2021), subsidence (Pennington et al., 2017), and neotectonics (Stanley, 2003), to which must be added the impact of human activities (Flaux et al., 2012).

The lagoon, whose water level is currently controlled by means of pumps and a canal to the Mediterranean Sea located at $\mathrm{Al}$ Max (in the vicinity of Alexandria), occupies parts of a depression, some areas of which are below mean sea level. This depression consists of two distinct areas (Fig. 1). To the east, its edges slope gently, and no significant topographical features separate it from the now-drained Abukir lagoon to the north-east, the delta to the east, the desert to the west and the agricultural lands of Al Buhayrah to the south. In the western part, often called wadi Mariut or Mariut valley, the depression stretches from east to west and is bordered by two steeply sloping calcarenite ridges separating it from the Mediterranean Sea in the north and from another depression in the south.

\subsection{Archaeological and historic settings $(\sim 1000 \mathrm{BCE}-\sim 1000 \mathrm{CE})$}

The archaeology of the western part of Lake Mareotis (wadi Mariut) has been investigated since the beginning of the 20th century (e.g. De Cosson, 1935). From the beginning of the 1st millennium BCE to the end of the 1st millennium CE, the following dynamics of occupation have been demonstrated: from the New Kingdom ( 1580 $\sim 1077$ BCE), occupation on high points on the northern and southern banks of the valley (Boussac et al., 2015; Empereur, 2018; Nenna et al., 2020); from the Saite Period (664-525 BCE) at the latest, agricultural development (wine) attested to in Plinthine on the northern bank (Redon et al., 2017); during the Hellenistic period (332-30 BCE), urban development in sectors located lower down on both banks and on Mariut island (Blue and Khalil, 2011; Boussac, 2015); and from the early Roman 


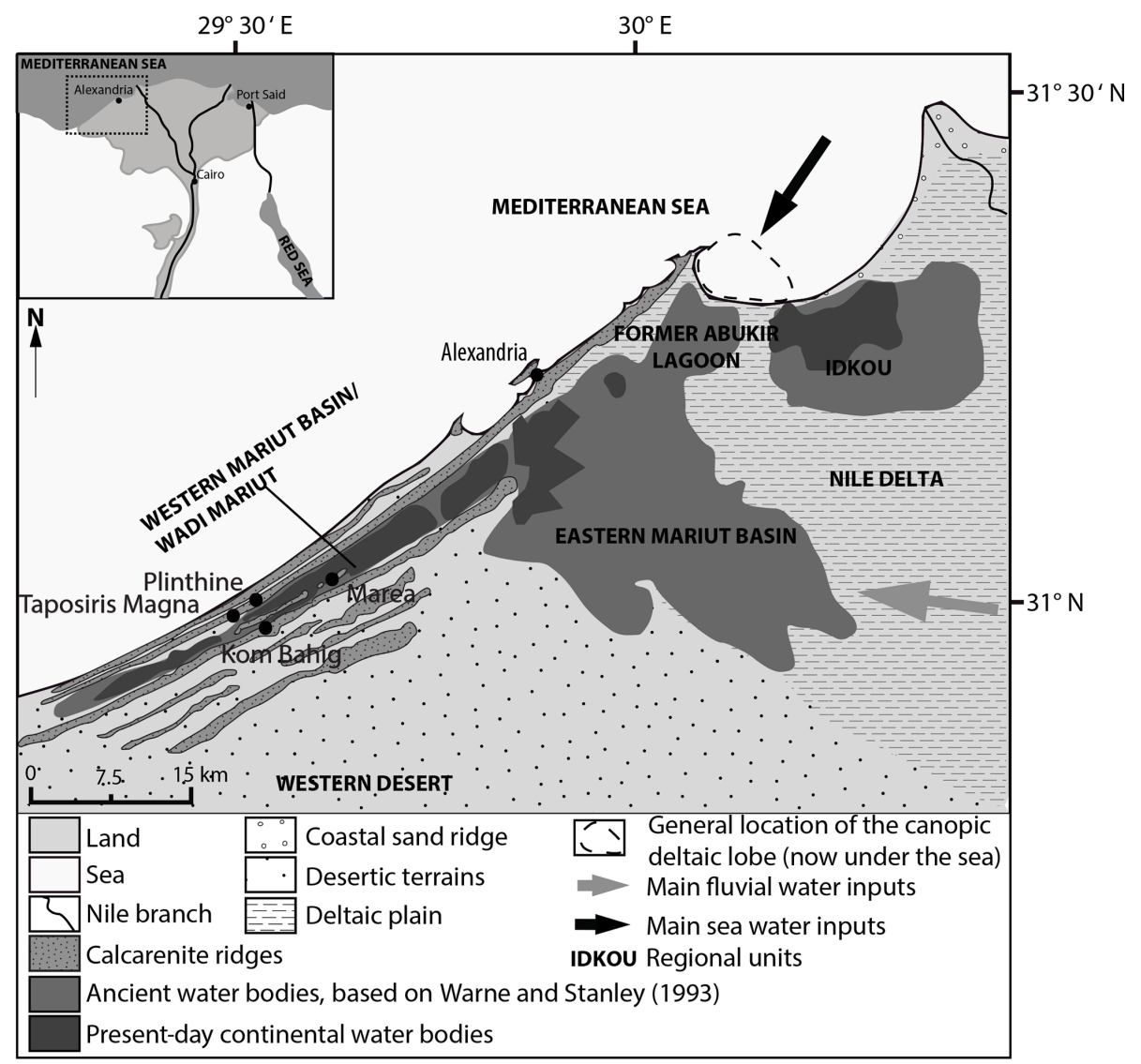

Figure 1. Main geomorphic units in the Mariut area, based on Flaux (2011).

period (30 BCE-284 CE) to the Arab-Islamic conquest (mid7th century $\mathrm{CE}$ ), increasing harbour and economic development (including wine export) (Décobert, 2002; Blue and Khalil, 2011; Boussac and El-Amouri, 2010; Dzierzbicka, 2018; Pichot and Simony, 2021). The Hellenistic and Roman periods are characterised by structures occupying areas that are very close to the current shores of the lake (or even in the present lake) and located at altitudes much lower than the remains of other periods, suggesting that the lake levels were lower during these periods or that the geometry of the lake was different. This has been demonstrated at Taposiris and on Mariut island (Blue and Khalil, 2011; Flaux, 2012).

\subsection{Previous geomorphological and geoarchaeological studies}

\subsubsection{Holocene history of the Mariut lagoon}

The calcarenite ridge separating the Mariut depression and the Mediterranean Sea, as well as the ridge delimiting the wadi Mariut to the south, predate the Holocene (El Asmar and Wood, 2000) and have durably limited the extension of the lagoon. The Holocene shifts of the lagoon were therefore mainly conditioned by the balance between sea level variations, subsidence, and the Nile's liquid and solid inputs, the latter being determined by climatic conditions and human activities in its watershed.

During the Holocene, the evolution of the Mariut region (Table 1) has been established by the work of Clément Flaux mainly thanks to data from the eastern part of the Mariut but also from Taposiris and from the southern bank of the wadi Mariut (Flaux et al., 2011; Flaux, 2011, 2012). From the early Roman period (30 BCE-284 CE), the evolution of the lagoon has been linked to the filling in of the Canopic branch (Fig. 1; Bernand, 1970; Hairy and Sennoune, 2009) and to the sinking of its deltaic lobe below sea level around the 8th century CE (Stanley et al., 2001).

\subsubsection{A geoarchaeological paradox}

This general environmental pattern cannot be directly applied to the wadi Mariut; on the one hand, subsidence is strong in the eastern part of the Mariut depression but very weak in wadi Mariut (Pennington et al., 2017), and on the other hand, marine and Nilotic water inputs both originate from the east (Fig. 1). Moreover, in wadi Mariut, Pleistocene outcrops are not uncommon and the Pleistocene-Holocene boundary is generally close to the topographic surface, so less sedimentation occurred during the Holocene (Flaux, 2012). 
Table 1. Holocene evolution of the Mariut region based on Flaux et al. (2011) and Flaux $(2011,2012)$.

\begin{tabular}{lll}
\hline Period & Status & Main causes \\
\hline$\sim 9000-\sim 7000 \mathrm{BCE}$ & $\begin{array}{l}\text { Coastal deltaic plain periodically } \\
\text { flooded by the Nile }\end{array}$ & Nile Delta progradation \\
\hline$\sim 6000 \sim 5500 \mathrm{BCE}$ & Lagoon sedimentation & Holocene marine transgression \\
\hline$\sim 5500-\sim 2800 \mathrm{BCE}$ & Lagoon closed to marine influences & Nile Delta progradation \\
\hline$\sim 2800-\sim 1200 \mathrm{BCE}$ & $\begin{array}{l}\text { Marine influence and hydrological in- } \\
\text { stability }\end{array}$ & $\begin{array}{l}\text { Climatic aridification and reduced Nile } \\
\text { flow }\end{array}$ \\
\hline$\sim 1000 \mathrm{BCE}-\sim 200 \mathrm{CE}$ & $\begin{array}{l}\text { Lagoon more subject to the Nilotic in- } \\
\text { fluence than to the maritime one and an- } \\
\text { thropogenic disturbances }\end{array}$ & $\begin{array}{l}\text { Canopic branch defluviation and } \\
\text { anthropogenic activities }\end{array}$ \\
\hline$\sim 200-\sim 800 \mathrm{CE}$ & $\begin{array}{l}\text { Brackish lagoon dominated by nilotic } \\
\text { inputs }\end{array}$ & To be determined \\
\hline$\sim 800-\sim 1200 \mathrm{CE}$ & Sebkha & Nile defluviation and canal siltation \\
\hline
\end{tabular}

Sedimentological and physico-chemical analyses have been interpreted as evidence of a large extension of the Mariut lagoon westward between $\sim 4000 \mathrm{BCE}$ and $\sim 1200 \mathrm{CE}$ even beyond the present limits of the lake (Warne and Stanley, 1993). A generally high water level in antiquity has also been assumed for Taposiris (Tronchère, 2010; Tronchère et al., 2014).

A lot of ancient harbour infrastructure has been prospected (Blue and Khalil, 2011) but also Hellenistic and Roman remains submerged or located close to the current shores of the lagoon, including amphora workshops (Empereur and Picon, 1998; Flaux, 2012). Their underground kilns make them incompatible with their proximity to the lake and high water levels. However, the operation of the few ports and sites bordering the lake studied in more detail implies relatively high water levels, for the Roman period at least, for example at Taposiris (Boussac and El Amouri, 2010) or on Mariut island (Flaux, 2012).

The archaeological remains and the environmental data from wadi Mariut thus present a geoarchaeological paradox to be solved. Not only do the environmental and archaeological data not converge, but even the archaeological data seem to contradict each other unless we consider a variability in water levels of high frequency, several independent lakes or water engineering on the scale of the wadi Mariut, whose remains have not yet been highlighted.

\subsubsection{Illustration of the geoarchaeological paradox: Taposiris harbour}

The lake complex of Taposiris (Fig. 2), investigated since 1998 by the French mission at Taposiris Magna and Plinthine, consists of a dug or deepened canal bordered to the south by an artificial sedimentary levee on which warehouses are lined up and to the north, at its eastern end, by dredging material. A bridge that connects the bank to the artificial levee is dated to early Roman times, more specifically to the 2nd century CE (Boussac and El Amouri, 2010). The artificial levee and the dredged material cover Hellenistic remains (2nd-1st century BCE), part of which is below the present water surface (Boussac and El-Amouri, 2010). To the east, a stone pier from the late Roman period (4th century $\mathrm{CE})$ closes the port complex. The swamp located to the north, which could suggest a harbour basin, was already a swamp during antiquity (Flaux, 2012).

The chronological sequence is as follows (Boussac and ElAmouri, 2010; Boussac, 2015):

- urban development during the 2nd-1st century BCE;

- building of an artificial levee during the 2nd century CE;

- raising of the artificial levee after the 4th century CE;

- installation of the eastern pier around the 4th century $\mathrm{CE}$;

- abandonment of the area after the 7th century CE.

\section{Material and methods}

Carrying out a geoarchaeological study in wadi Mariut is complex due to the lack of analysis equipment and to Egyptian legislation prohibiting the export of samples. Moreover, urbanisation and agricultural development in the region in the 20th century has considerably altered the topography and sedimentary formations of the region (quarries, salt ponds, etc.). We therefore used a combination of methods to overcome these obstacles. 


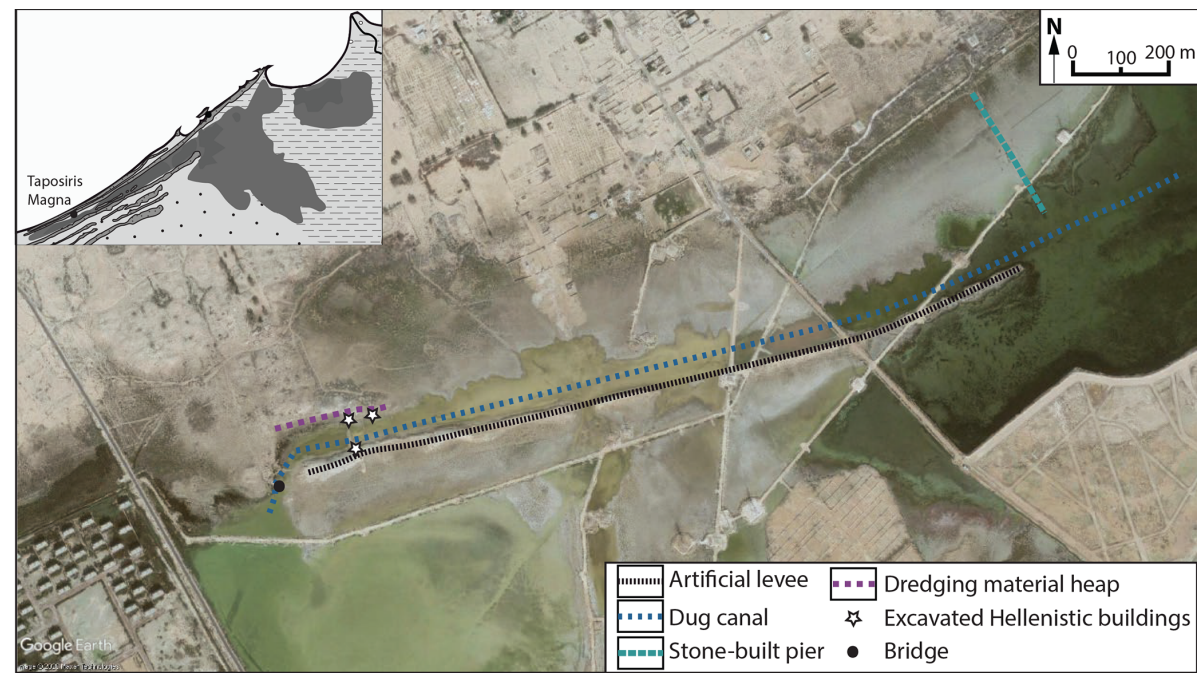

Figure 2. Harbour of Taposiris. Base map image: (c) Google Earth Pro November 2009.

\subsection{Reassessment of geoarchaeological data}

We reassessed and crossed three types of data that led researchers to reconstruct a large extension of Lake Mareotis in wadi Mariut:

- sedimentological, biological and physico-chemical data (available in Tronchère, 2010; Tronchère et al., 2014; Warne and Stanley, 1993);

- archaeological data, in particular the distribution of sites (from Blue and Khalil, 2011 and Boussac, 2015);

- historical data, through an analysis of two sources frequently used in the study of the region (Strabo, 2015:17; Jacotin, 1818).

\subsection{Early scholars' accounts (1800-1945)}

A total of 11 early western scholars' contributions (Chabrol and Lancret, 1829; De Cosson, 1935; El Falaki, 1872; Le Père, 1823, 1825, 1829; Jacotin, 1824; Oliver, 1945; Reclus, 1885; Rennell, 1800; St John, 1849) have been selected and studied to recover data erased over time. They describe a period during which human activities were less developed than today and provide additional elements on archaeology, completing the data concerning the distribution of the sites and the topography.

\subsection{Maps (1807-1958)}

Eight maps (Table 2) have been analysed to identify the topography of the lands currently flooded and the vanished archaeological sites and to characterise the recent evolution of the extension of the lake.

\subsection{Corona photographs}

Three declassified satellite photographs from the Corona programme (Table 3) were acquired free of charge on EarthExplorer (https://earthexplorer.usgs.gov/, last access: 22 January 2021).

They allow us to evaluate the topography of the nowflooded areas and to observe the region before its current development. Moreover, they help us to escape the subjectivity of early scholars and the bias of cartographic surveys in swampy areas and to observe the terrain from the sky to identify macrostructures.

\section{Results and interpretation}

\subsection{Reassessment of geoarchaeological data}

\subsubsection{Sedimentological data: playa, lake or lakes?}

Two studies led to the reconstruction of a large extension of Lake Mareotis in its western part: Warne and Stanley (1993) at the regional scale and Tronchère (2010) and Tronchère et al. (2014) around Taposiris. The first study (Warne and Stanley, 1993) was based on the analysis of sedimentary cores and revealed the presence of a lagoon dominated by fluvial inputs throughout wadi Mariut and up to Taposiris in the west $\sim 2500 \sim 2000$ years ago. If only the regional scale and major trends are considered, these conclusions are correct, although a reassessment is needed at the local scale and is made possible by the rigour of Warne and Stanley (1993) in presenting their data. At the scale of wadi Mariut, the data highlight three points:

- on several isopleth maps (Fig. 3), the Nilotic influence does not appear (verdine/glauconite) or appears very slightly (mica, heavy minerals) in the western part of 
wadi Mariut, and other parameters strongly differentiate it (gypsum, foraminifera);

- the Holocene sedimentary column represents less than $2.5 \mathrm{~m}$ in most of wadi Mariut;

- in the western part of wadi Mariut, the only facies that can be linked to a lagoon are "lagoon margin mud" facies whose composition could just as well correspond to playa or semi-playa deposits (as described by Embabi, 2004, and by Crépy, 2016).

The continuity of the lagoon up to Taposiris is therefore not established by Warne and Stanley's data (1993) which show, in contrast, that at least one basin has undergone a specific evolution (Fig. 3).

Data from Tronchère (2010) and Tronchère et al. (2014) at local scale led to the reconstruction of a lake or lagoon reaching Taposiris during the whole Holocene (the alteration layer of the calcarenite substratum was dated to 40254 $\left.38032 \mathrm{cal} \mathrm{BCE}^{1}\right)$. However, the very small quantity of ostracods found (some samples were totally free of them) and the granulometric data do not go in this direction. The laser granulometry curves are all multimodal, which Tronchère (2010) attributed to a sampling bias. The presence of recurrent aeolian modes (loess: 10-20 $\mu \mathrm{m}$; dune sand: 100-200 $\mu \mathrm{m}$; according to Tsoar and Pye, 1987) mixed with other modes would rather indicate a palustrine environment influenced by desert dynamics (e.g. playa or sebkha margin). To sum up, the sedimentological data are more likely to correspond to marshy or immersed areas disconnected from the Mariut lagoon.

\subsubsection{Historical data: some necessary precautions}

Strabo's Book 17 (Strabo, 2015:17) and Jacotin's map (1818) are often used to study Lake Mareotis' extension during antiquity. According to the ancient geographer, the lake measured, in his time, 150 stadia $(\sim 27.75 \mathrm{~km})$ or more in width and less than 300 stadia $(\sim 55.5 \mathrm{~km})$ in length (Strabo, 2015:17, 14). These measurements have generally been interpreted in light of the current state of the lake, and the orientation has often been used as follows: 300 stadia from the north-east to south-west and 150 stadia from the north-west to south-east. However, there is no indication of this orientation in Strabo's text, and data on the Holocene evolution of the Nile Delta and on subsidence in the eastern Mariut basin would rather fit with an opposite orientation, especially if one takes into account a Nilotic influence.

Jacotin's map (1818) has sometimes been used as a reference state of ancient Mariut (e.g. Tronchère et al., 2014) even if the limits of the lake have been drawn after a British military operation, as mentioned on the map, "Cuts made

\footnotetext{
${ }^{1}$ Calibration by M. Crépy with OxCal using IntCal20 calibration curve based on raw data from Tronchère et al. (2014).
}

by the English to flood Lake Mareotis (19 Germinal An 919 April 1801)". The lake on the map corresponds to a state when it was directly connected to the Aboukir lagoon, itself open to the sea, and therefore at a much higher level than the maxima during most of the studied period (4th century BCE-8th century $\mathrm{CE}$ ) when the Canopic deltaic lobe used to be an obstacle to links with the Mediterranean Sea (Stanley et al., 2001).

\subsubsection{Archaeological data}

The spatio-temporal distribution of the sites could seem relevant to draw the ancient shores of the lake. However, two obstacles prevent the proper exploitation of the survey results (e.g. Blue and Khalil, 2011; Picon and Empereur, 1998). In the absence of underwater surveys, the distribution of sites is incomplete and draws a shoreline corresponding to the limit of the lake at the time of the survey (even if Blue and Khalil, 2011, also mentioned some underwater remains, they saw from the land), and surface surveys are not sufficient to give an exhaustive chronology of the sites. However, the following observations can be made thanks to the Hellenistic and Roman amphora workshops of Mariut island and Borg el Arab (surveyed by Empereur and Picon, 1998, and Blue and Khalil, 2011; Fig. 4). The altitude of their kilns shows that the lake must have been located within more restricted limits or at a lower level than today in this part of wadi Mariut. The kilns of this area are indeed located below the top of the phreatic water table induced by the current lake. Similar levels inferred for antiquity would thus hinder their use. Likewise, the Hellenistic quarter of the lower town of Taposiris is incompatible with the present level of the lagoon (Flaux, 2012)

\subsection{Early scholars' accounts (1800-1945)}

\subsubsection{Limits of the lake(s)}

Before the flooding in 1801, low areas of the Mariut depression could fill with water after rainfall (Chabrol and Lancret, 1829; Le Père, 1825) and form small independent lakes, for example southwest of Taposiris (St John, 1849). At the peak of the flood, the western limit of the water would have been located at the level of the so-called Arabs' tower (Jacotin, 1824) or $1000 \mathrm{~m}$ east of Taposiris (Le Père, 1829) or about $500 \mathrm{~m}$ east of the Arabs' tower (Fig. 5). W. G. Browne, at the end of the 18th century, saw no reason to consider a lake that would have been more than 1 or 1.5 leagues $(\sim 4.83$ or $\sim 7.25 \mathrm{~km}$ ) from Alexandria in the past based on the observation of the ground and the topography (Rennell, 1800).

\subsubsection{Data on archaeological remains}

Early scholars mention remains that have now disappeared, such as walls and canals in wadi Mariut (Chabrol and Lancret, 1829), as well as levees or small dikes (now under wa- 
Table 2. Maps used in this study.

\begin{tabular}{lll}
\hline Date & Author & Link \\
\hline 1807 & Arrowsmith & $\begin{array}{l}\text { https://gallica.bnf.fr/ark:/12148/btv1b530669569/ } \\
\text { (last access: 22 January 2021) }\end{array}$ \\
\hline 1818 & Jacotin & $\begin{array}{l}\text { https://gallica.bnf.fr/ark:/12148/btv1b531569998/ } \\
\text { (last access: 22 January 2021) }\end{array}$ \\
\hline 1827 & Coste & $\begin{array}{l}\text { https://gallica.bnf.fr/ark:/12148/btv1b8491814n/ } \\
\text { (last access: 22 January 2021) }\end{array}$ \\
\hline 1850 & St John & $\begin{array}{l}\text { https://gallica.bnf.fr/ark:/12148/btv1b53136219p/ } \\
\text { (last access: 22 January 2021) }\end{array}$ \\
\hline 1866 & El Falaki & $\begin{array}{l}\text { https://gallica.bnf.fr/ark:/12148/btv1b10101071m/ } \\
\text { (last access: 22 January 2021) }\end{array}$ \\
\hline 1910 & Survey of & $\begin{array}{l}\text { https://www.davidrumsey.com/luna/servlet/detail/ } \\
\text { RUMSEY 8 1 317305 90086593:Sheet-47-Bahig } \\
\text { (last access: 22 January 2021) }\end{array}$ \\
\hline 1942 & AMS & $\begin{array}{l}\text { http://legacy.lib.utexas.edu/maps/ams/egypt/ } \\
\text { txu-pclmaps-oclc-6559596-el-hammam.jpg } \\
\text { (last access: 22 January 2021) }\end{array}$ \\
\hline 1958 & AMS & $\begin{array}{l}\text { http://legacy.lib.utexas.edu/maps/ams/north_africa/ } \\
\text { txu-oclc-6949452-nh35-8.jpg (last access: 22 January 2021) }\end{array}$ \\
\hline
\end{tabular}
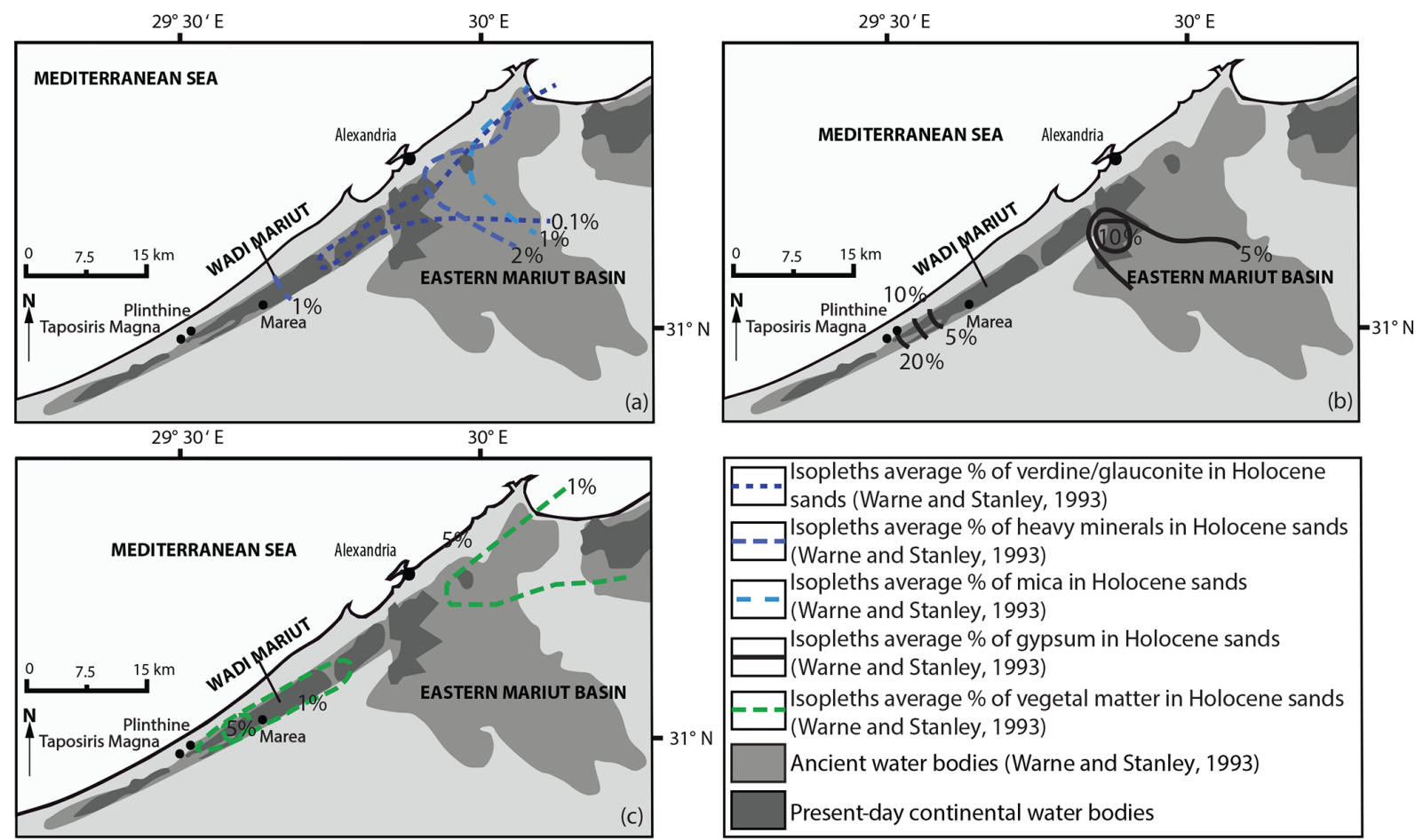

Figure 3. (a) Isopleths (based on Warne and Stanley, 1993) recording the Nile's influence on the Mariut basin. (b) Isopleths (based on Warne and Stanley, 1993) indicating high evaporation processes during the Holocene in the western part of wadi Mariut. (c) Isopleths (based on Warne and Stanley, 1993) emphasising specific local dynamics in wadi Mariut. 


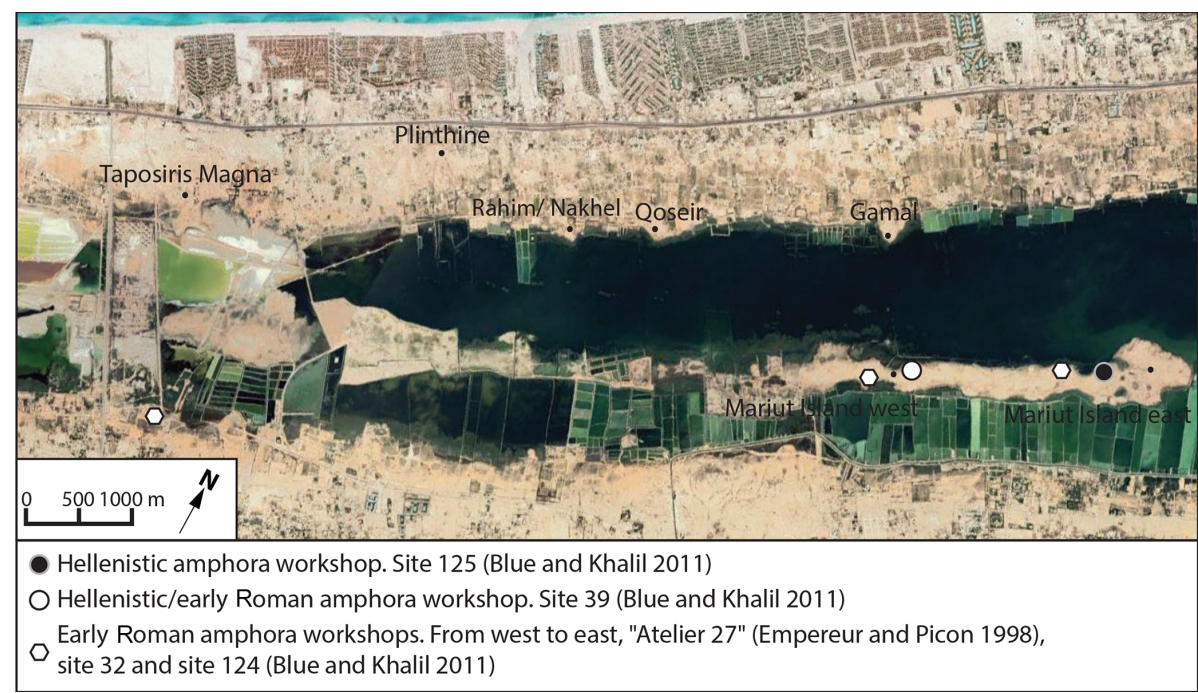

Figure 4. Amphora workshops in the area (base map image: $\odot$ Google Earth Pro).

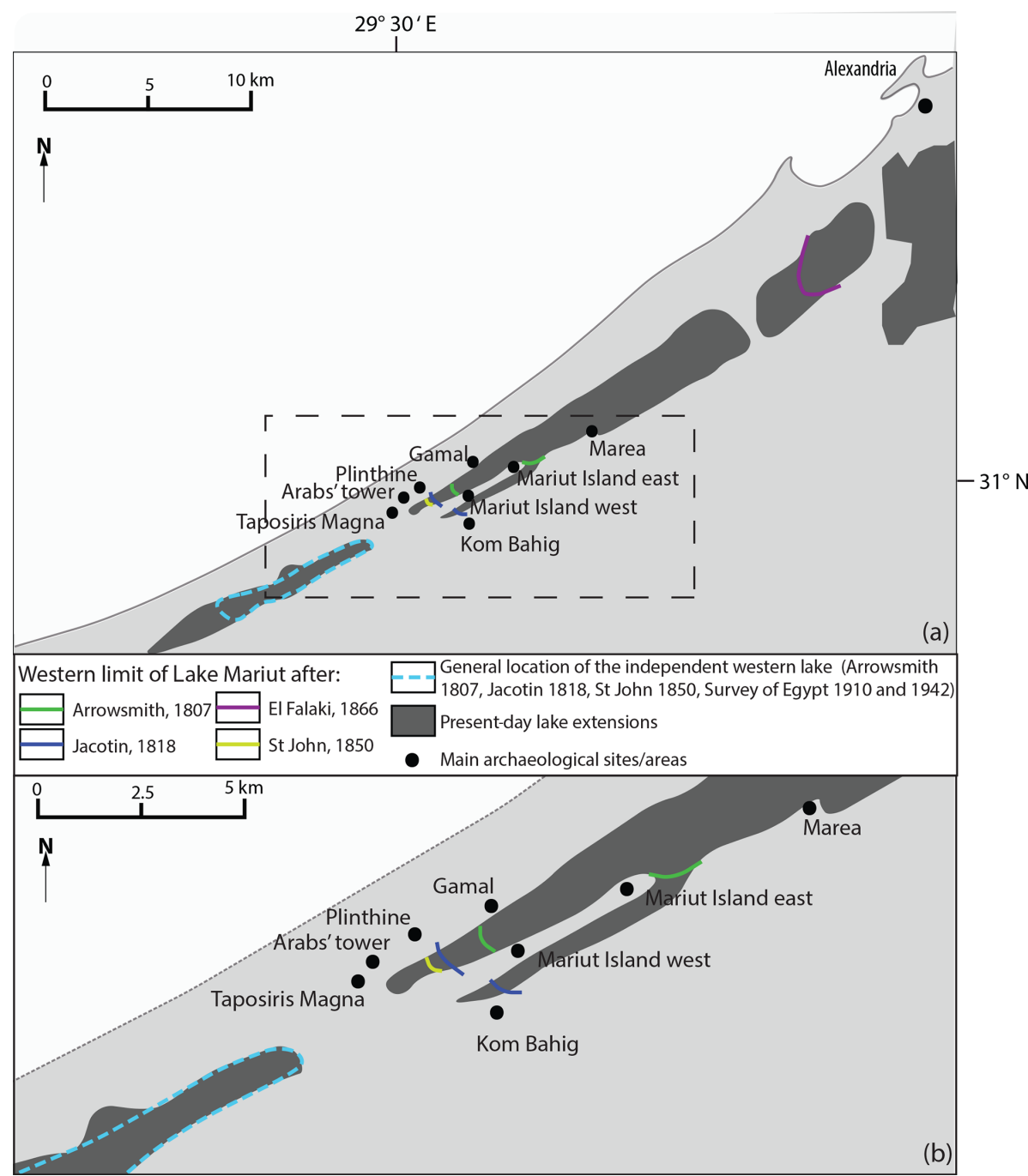

Figure 5. Limit of the lakes according to old maps. (a) Regional scale. (b) More local scale. 
Table 3. Corona photographs used in this study.

\begin{tabular}{ll}
\hline Corona ID & Acquisition (mm/yyyy) \\
\hline DS1016-2088DF007 & $01 / 1965$ \\
DS1109-2171DF010 & $03 / 1970$ \\
DS1111-2167DA024 & $08 / 1970$ \\
\hline
\end{tabular}

ter) which were spanned by small bridges and crossed the wadi Mariut (Le Père, 1823). El Falaki (1872) even mentions entire sites (destroyed by modern construction) extending over $9 \mathrm{~km}$ north-east of Taposiris, thus offering a counterpart on the north bank to the succession of sites still visible on the south bank (Blue and Khalil, 2011; Pichot and Simony, 2021). Because of the presence of underwater remains, some early scholars speculated that the lake was completely or partially desiccated during part of antiquity without specifying a precise period (e.g. Reclus, 1885).

\subsubsection{Data on Taposiris artificial levee}

Some early scholars described the harbour complex of Taposiris, bringing two pieces of information that have now been erased. The west-east artificial levee of Taposiris was doubled by an ancient causeway (De Cosson, 1935), and a second canal dug across the wadi Mariut from north to south linked Taposiris harbour to a dock on the south side of the valley and was doubled with a causeway located on the sedimentary levee forming the west bank of the canal (Oliver, 1945).

\subsection{Maps (1807-1958)}

\subsubsection{Extension of the lake(s)}

For all but one (St John, 1850) of the studied maps, the lake did not reach the Arabs' tower even in the periods following the flood of 1801 (Fig. 5). Wadi Mariut is often depicted as being occupied exclusively by marshes (El Falaki, 1866; on a smaller area, Survey of Egypt, 1910, 1942) or being completely dry (AMS, 1958). The boundaries of the lake, whether dried up (Coste, 1827) or in water (Arrowsmith, 1807; Jacotin, 1818), extend farther to the east-south-east in its eastern part than to the west in wadi Mariut, which is in favour of a reinterpretation of the measurements given by Strabo (cf. Sect. 4.1.2). Finally, a small independent lake or marsh is drawn to the west of Taposiris (Fig. 5) in five out of six maps covering this sector (Arrowsmith, 1807; Jacotin, 1818; St John, 1850; Survey of Egypt, 1910, 1942).

\subsubsection{Subaquatic topography}

One map (AMS, 1958) gives an insight into the now-flooded topography of the bottom of wadi Mariut; the western part of wadi Mariut includes several closed basins whose elevations are below mean sea level and are separated by topographic thresholds and higher areas.

\subsubsection{Mention of ruins and remains}

The ruins are numerous on both banks of wadi Mariut, as well as on islands and even in the marshy part at its bottom (El Falaki, 1866). To the south of Taposiris and near Kom Bahig, a map (St John, 1850) shows the remains of catacombs and an excavation on the opposite bank. Many dikes, causeways or bridges are also indicated (Jacotin, 1818); there is one causeway between Marea and Sidi Kirayr and a second between Gamal and Mariut island, and elements of dikes or causeways are represented at Taposiris. Finally, the dug canal of the port of Taposiris appears clearly on two maps; El Falaki (1866) indicates in addition to this canal, which he extends to the west, a second canal towards the south in accordance with the descriptions of Oliver (1945; cf. Sect. 4.2.3), and Arrowsmith (1807) roughly draws the shape of the westeast canal and designates it as "Remains of an ancient canal from the Nile". Unfortunately, travellers' descriptions do not make it possible to assess precisely the dating of the remains, but the low occupation of the area from the end of the 7th century CE (Décobert, 2002) until at least the end of the 18th century (Hairy and Sennoune, 2009) makes an ancient dating very likely. Moreover, concerning the canals, neither the books of Coste (1878) and Linant de Bellefonds (1873), who worked on agricultural projects in the region, nor the topographical maps of the 20th century mention the canals, which confirms that they were not made in the 19th or 20th centuries.

\subsection{Corona photographs: canals in wadi Mariut}

In the photographs used, the levels and extent of the lake are lower than they are today as the agricultural projects that now bring in large amounts of surplus irrigation water were still in their initial stages. In the photograph of August 1970 in particular, the level is very low because of summer evaporation and scarce rainfall, whereas it is higher in the two other ones (March 1970 and January 1965). In the photographs, it appears that in the western part of wadi Mariut, several of the closed basins are linked by two large canals or channels (the longest being more than $12 \mathrm{~km}$ ) joined to the west of Gamal. From there, a unique canal extends discontinuously up to the artificial levee of Taposiris and further south-west and then west from the Roman bridge of Taposiris where it ends in the small lake mentioned in maps and accounts (Fig. 6). The maximal width of the two joint canals is around $80 \mathrm{~m}$. They border some depressions which could have been harbour basins as they are located close to sites including ancient piers (Fig. 6). The north-south canal (reported by El Falaki, 1866; Oliver, 1945) is also visible.

Some shorter, narrow canals branch to the two main ones and join sites to the south. It is difficult to determine whether 

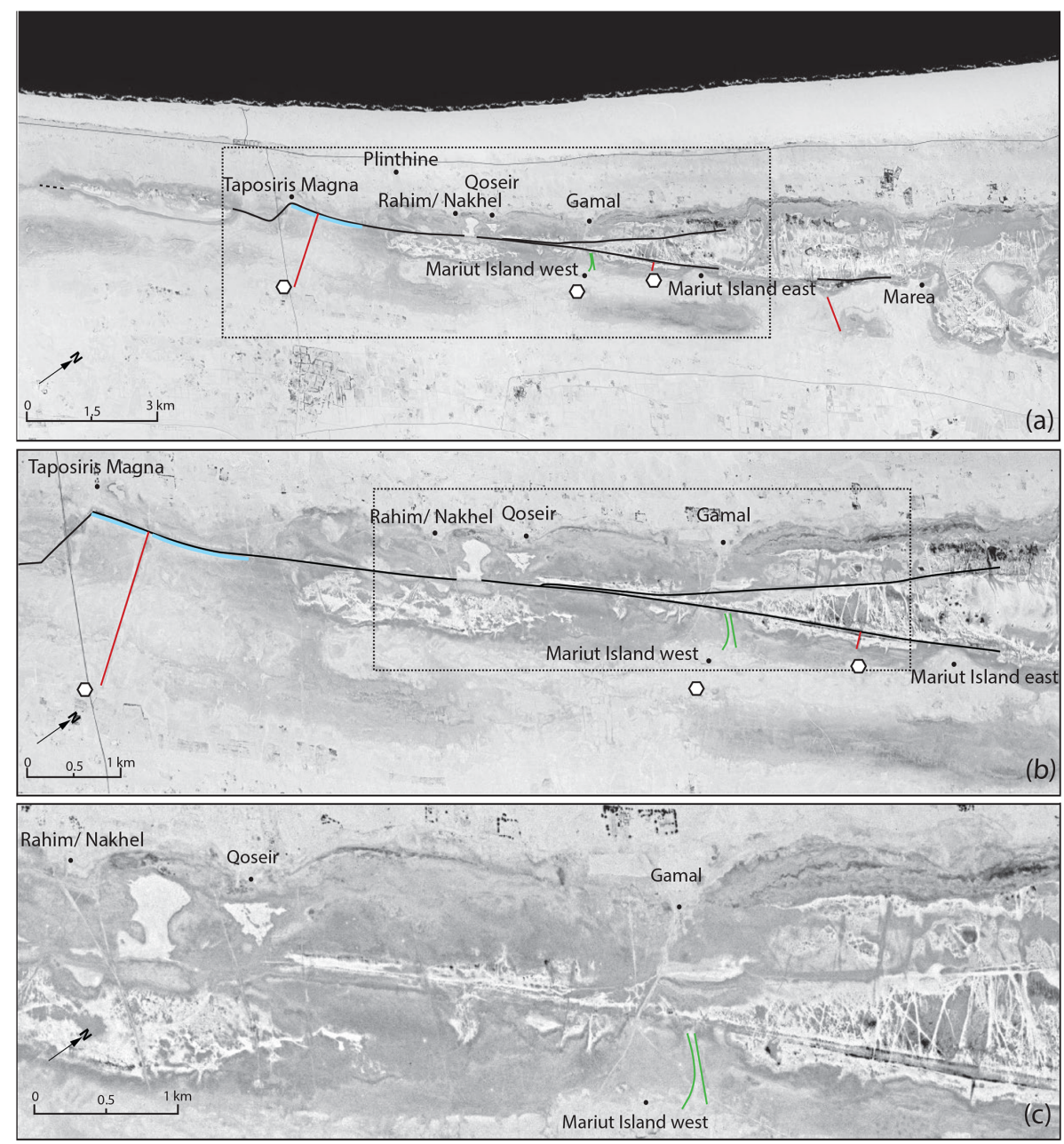

Main canals Secondary canals
Artificial levee of Taposiris Harbour, built during the 2nd c. CE
Kilns whose operating time is exclusively comprised between the mid-1st and mid-3rd c. CE
(AE4 production). From west to east, "Atelier 27" (Empereur and Picon, 1998), site 32 and site 124
(Blue and Khalil, 2011)
Jetty-like structure whose construction is dated from between the mid-1st and mid-3rd c. CE,
site 23 (Blue and Khalil, 2011)

Figure 6. Corona photograph DS1111-2167DA024 (USGS). (a) Canal from Marea to the west of Taposiris. (b) Focus on the central area. (c) Details of the canals.

these canals were deepened channels in flooded areas or if they were canals dug in dry or marshy areas. However, the shapes of the banks of rubble along some parts of the two main canals indicate digging in an environment dry enough for the rubble to remain despite the high proportions of silt and clay at the bottom of wadi Mariut.

\section{Discussion}

\subsection{Solving the paradox: lakes and canals}

The combination of all these elements shows that for certain periods of the Holocene, there was not a unique Mar- iut lake but several lakes occupying closed depressions (cf. Sects. 4.1, 4.2, 4.3.2, 4.4) which could be filled by rainfall. The creation of canals (cf. Sect. 4.4) made it possible to connect them by crossing the topographic thresholds (cf. Sect. 4.3.2). In this way, it was possible to have harbour infrastructures without a continuous stretch of water. These canals are connected to the Taposiris harbour canal, whose digging is firmly dated to the 2nd century CE, and they border several sites that were occupied during the same period, including three amphora kilns whose construction is dated between the mid-1st and the mid-3rd centuries CE (Fig. 6). It is therefore probable that the canals were built during the 


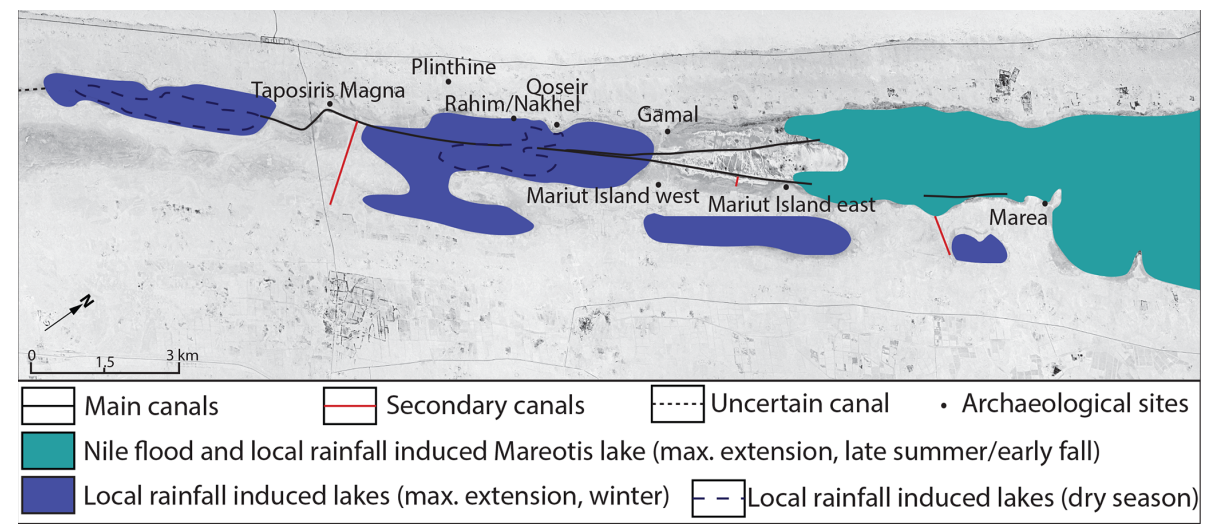

Figure 7. Corona photograph DS1111-2167DA024 (USGS). Proposed extension of the lakes in wadi Mariut during the Hellenistic and early Roman period. Coloured patches correspond to maximum extensions.

Roman period as a harbour complex including several sites (including Taposiris, Mariut island, Marea, etc.). Under these conditions, it becomes easier to understand how Roman harbours could have been in the direct vicinity of Roman amphora kilns; it was not an extensive lake with a highly developed underground water table but smaller basins connected to each other by canals. This interpretation pattern is fully consistent with previously published sedimentological data (e.g. Warne and Stanley, 1993; Tronchère, 2010; Tronchère et al., 2014; Flaux, 2012). Obviously, the chronology will have to be refined by fieldwork at the scale of the wadi Mariut. The magnitude of the works raises a question: for what reasons were canals and at least one bridge built? This article alone cannot provide a complete answer, but it is likely that in an Egyptian climatic context dominated by hyper aridity, the agricultural opportunities offered by the Mediterranean winter rainfall and the natural concentration of surface water in wadi Mariut justified the efforts in connection with the export of local agricultural productions (e.g. wine).

\subsection{New hypothesis on Mareotis lake(s) evolution}

During the first part of the period under study (first half of the 1st millennium BCE), the archaeological remains were mainly found in high areas, which could lead to the assumption of high lake levels compatible with the palaeoenvironmental data (from Flaux, 2012), but the lack of archaeological excavations calls for caution. In contrast, it is clear that during the Hellenistic and early Roman periods, the water levels were lower, and the extension of the water was smaller (Fig. 7) thanks to the presence of numerous sites incompatible with a single large lake. This reduction can be explained both by the progradation of the Canopic lobe closing off the Bay of Aboukir and the connection to the sea (Flaux, 2012) and by the canal of Alexandria, depriving the lake of part of the Nile flood to the benefit of the city's water supply. The urban and agricultural development of this period could therefore partly explain the ruins mentioned by the early scholars and the maps at the bottom of the wadi Mariut, which are located in some of the topographic threshold areas separating the closed depressions. However, flooding during intense rainfall or an exceptional Nile flood cannot be excluded.

During the Roman period, the digging of the canal artificially re-established the connectivity between the lakes of the wadi Mariut and linked all the sites to Lake Mareotis proper in the east and thus to Alexandria, the Nile and the Mediterranean, contributing to the economic growth of the region. Finally, the construction of the stone jetty at Taposiris after the 4th century CE, which includes a fish pond, as well as the raising of the levee after the 4th century CE (Boussac and El Amouri, 2010), seems to indicate a rise in the water level which could be linked to the gradual subsidence of the Canopic branch (Stanley et al., 2001) or greater Nile floods. This rise has also been demonstrated near Marea (Pichot and Flaux, 2015). Our study does not allow us to know more, but that of Flaux (2011) indicates a severe drying up as early as the 9 th century CE.

\section{Conclusion and perspectives}

This article returns to a subject already addressed by classical sedimentological methods of geoarchaeology. This type of data alone, although obviously necessary to study past environments, was not sufficient to solve the paradox of the wadi Mariut. Combining it with geohistorical sources (Corona photographs, maps, accounts of early scholars) allows for new interpretations. They provide a complementary vision of the spatial organisation, landscapes and environmental dynamics prior to the profound changes in this region since the 1980s.

They allow for the development of a model of the evolution of the wadi Mariut from the beginning of the Hellenistic period (late 4th century BCE) to the beginning of the Medieval period (8th century CE). The lake first experienced a period of drying up followed by urban and agricultural devel- 
opment, including in some sectors of the bottom of the wadi Mariut. During the Roman period in the 2nd century CE, a system composed of large canals was set up, linking independent basins to each other and to the large Lake Mareotis (the lake actually described by Strabo) in the east. After the 4th century CE, higher water levels are likely, before drying up in the 9th century CE (Flaux, 2012). Refining and completing this chronology and this model, as well as studying the canals in detail (possible locks, variability of water levels, etc.) now requires us to go back to the field and start new coring and excavations. It is also a starting point for a new analysis of regional economy and history.

Data availability. The reassessed sedimentological datasets are available in the articles cited in the paper. All the maps are available free of charge on online platforms (last access: 22 January 2021): http://legacy.lib.utexas.edu/ maps/ams/egypt/txu-pclmaps-oclc-6559596-el-hammam.jpg

(AMS, 1942), http://legacy.lib.utexas.edu/maps/ams/north_ africa/txu-oclc-6949452-nh35-8.jpg (AMS, 1958), https: //gallica.bnf.fr/ark:/12148/btv1b530669569/ (Arrowsmith 1807), https://gallica.bnf.fr/ark:/12148/btv1b8491814n/ (Coste, 1827), https://gallica.bnf.fr/ark:/12148/btv1b10101071m (El Falaki, 1866), https://gallica.bnf.fr/ark:/12148/btv1b531569998/f42.item (Jacotin, 1818), https://gallica.bnf.fr/ark:/12148/btv1b53136219p/ (St John, 1850), https://www.davidrumsey.com/luna/servlet/ detail/RUMSEY 8 1 317305 90086593:Sheet-47-Bahig (Survey of Egypt 1910). These URLs are also indicated in the References. Most of the traveller or early scholar accounts used in this paper are available free of charge on online platforms (last access: 22 January 2021): https://gallica.bnf.fr/ark: /12148/bpt6k28016p/f1.item.r=descriptiondel\{'\} egypte

(Chabrol and Lancret, 1829; Le Père, 1829), https: //books.google.fr/books?id=yWo3AQAAMAAJ\&printsec= frontcover $\& \mathrm{hl}=\mathrm{fr} \# \mathrm{v}=$ onepage $\& \mathrm{q} \& \mathrm{f}=$ false $\quad($ Coste, 1878), https: //gallica.bnf.fr/ark:/12148/bpt6k280140.r=descriptionel\{'\} egypte (Jacotin, 1824), https://gallica.bnf.fr/ark:/12148/bpt6k2991761/ f9.item.r=dictionnaire $\% 20 \mathrm{des} \% 20 \mathrm{~d} \% \mathrm{C} 3 \%$ A9couvertes $\%$

20mou\%20-\%20pat (Le Père, 1823), https://gallica.bnf.fr/ark: /12148/bpt6k28013n.r=descriptiondel\{'\}egypte (Le Père, 1825), https://books.google.de/books?id=tepYAAAAYAAJ\&printsec= frontcover $\& \mathrm{hl}=\mathrm{fr} \# \mathrm{v}=$ onepage $\& \mathrm{q} \& \mathrm{f}=$ false $\quad$ Linant de Bellefonds, 1873), https://archive.org/details/geographicalsys00renn/ page/n7/mode/2up (Rennell, 1800), https://archive.org/details/ adventuresinliby00stjo/page/n7/mode/2up (St John, 1849). These URLs are also indicated in the References. Corona photographs are available free of charge at https://earthexplorer.usgs.gov/ (USGS, 2021) using the following Corona ID (also provided in Table 3): DS1016-2088DF007, DS1109-2171DF010, DS1111-2167DA024.

Author contributions. MC carried out the reassessment of sedimentological, archaeological and historical data, as well as the collection and analysis of maps, early scholars' accounts, and Corona photographs. MFB contributed to the reassessment of the archaeological and historical data, as well as to the collection of maps and early scholars' accounts. MC took charge of the writing of the paper, MFB amended and approved it.

Competing interests. The authors declare that they have no conflict of interest.

Special issue statement. This article is part of the special issue "Geoarchaeology of the Nile Delta". It is a result of the workshop "Geoarchaeology of the Nile Delta: Current Research and Future Prospects”, Würzburg, Germany, 29-30 November 2019.

Acknowledgements. This study has been done as part of the French mission at Taposiris Magna and Plinthine with the kind authorisation of the Egyptian Ministry of Antiquities. We thank Bérangère Redon and Ninon Blond for their suggestions. We thank the anonymous referee and Judith Bunbury for their reviewing works. We warmly thank the editors of this special issue and the organisers of the workshop "Geoarchaeology of the Nile Delta: Current Research and Future Prospects".

Financial support. This research was funded by the French Institute of Oriental Archaeology (IFAO), HiSoMA (MOM) and the French Ministry of Foreign Affairs. The open-access publication was partly funded by DEUQUA and partly by the Shelby White and Leon Levy Program for Archaeological Publications.

Review statement. This paper was edited by Julia Meister and reviewed by Judith Bunbury and one anonymous referee.

\section{References}

AMS: El Hammam 88/42, available at: http://legacy.lib.utexas.edu/ maps/ams/egypt/txu-pclmaps-oclc-6559596-el-hammam.jpg (last access: 22 January 2021), 1942.

AMS: Burg El Arab, Serie P-502, available at: http://legacy.lib. utexas.edu/maps/ams/north_africa/txu-oclc-6949452-nh35-8. jpg (last access: 22 January 2021), NH35-8, 1958.

Arrowsmith, A.: Map of Lower Egypt, available at: https:// gallica.bnf.fr/ark:/12148/btv1b530669569/ (last access: 22 January 2021), 1807.

Awad, I.: A Study of the Evolution of the Maryut Lake through Maps, in: Lake Mareotis Conference: Reconstructing the past, Universities of Southampton and Alexandria, Alexandria, Egypt, 2008, edited by: Blue, L. and Khalil, E., Archaeopress, Oxford, UK, 11-33, 2010.

Bernand, A.: Le Delta égyptien d'après les textes grecs. 1 - les confins libyques, IFAO, Le Caire, 1970 (in French).

Blue, L. K. and Khalil, E.: A multidisciplinary approach to Alexandria's economic past: The Lake Mareotis research project, Archaeopress, Oxford, UK, 2011.

Boussac, M.-F.: Recent works at Taposiris and Plinthine, Bulletin de la Société archéologique d'Alexandrie, 49, 189-217, 2015. 
Boussac, M.-F. and El-Amouri, M.: The lake structures at Taposiris, in: Lake Mareotis Conference: Reconstructing the past, Universities of Southampton and Alexandria, Alexandria, Egypt, 2008, edited by: Blue, L. and Khalil, E., 87-105, Archaeopress, Oxford, UK, 2010.

Boussac, M.-F. and Redon, B.: L'intégration des confins nordouest de l'Égypte du Nouvel Empire à l'époque ptolémaïque. À propos des découvertes archéologiques récentes à Plinthine et Taposiris Magna (côte méditerranéenne, région du lac Mariout), in: Western borders and margins of Egypt from Antiquity to the Middle Ages, edited by: Boussac, M.-F., Dhennin, S., Redon, B., Somaglino, C., and Tallet, G., IFAO press, in press, 2021 (in French).

Boussac, M.-F., Dhennin, S., and Redon, B.: Plinthine et la Maréotide Pharaonique, BIFAO, 115, 15-35, 2015 (in French).

Chabrol, G. and Lancret, M. A.: Notice topographique sur la partie de l'Egypte comprise entre Rahmanyeh et Alexandrie, et sur les environs du lac Mareotis, available at: https://gallica.bnf. fr/ark:/12148/bpt6k28016p/f1.item.r=descriptiondel' egypte (last access: 22 January 2021), in: Description de l'Égypte, C.L.F. Pancoucke, Paris, France, 18, 2, 3-28, 1829 (in French).

Coste, P.-X.: Carte de la Basse-Égypte dédiée à Mohammed Aly Pacha, available at: https://gallica.bnf.fr/ark: /12148/btv1b8491814n/ (last access: 22 January 2021), vice Roi, 1827.

Coste, P.-X.: Mémoires d'un artiste. Notes et Souvenirs de voyages (1817-1877), available at: https://books.google.fr/books?id= yWo3AQAAMAAJ\&printsec $=$ frontcover $\& \mathrm{hl}=\mathrm{fr} \# \mathrm{v}=$ onepage $\&$ q\&f=false (last access: 22 January 2021), Marseille, Cayer et Cie, Marseille, France, 1878 (in French).

Crépy, M.: Géomorphologie et environnement du site de la nécropole de Plinthine, in: La nécropole hellénistique de Plinthine, IFAO press, Le Caire, in press, 2021 (in French).

Crépy, M.: Les Paysages du vent: géohistoire et géoarchéologie de la dépression de Kharga (désert Libyque, Égypte) du cinquième siècle avant notre ère à nos jours, $\mathrm{PhD}$ thesis, Université Lumière Lyon 2, France, Université de Lyon, 2 December 2016, available at: https://hal.archives-ouvertes.fr/tel-01490559/document (last access: 23 March 2017), 2016 (in French).

Dalongeville, R. and Fouache, E.: Les variations de la ligne de rivage en mer Méditerranée orientale du Pléistocène supérieur et de l'Holocène récent: réflexions, Paleo, 31, 27-38, https://doi.org/10.3406/paleo.2005.4781, 2005 (in French).

De Cosson, A.: Mareotis, Country Life Ltd., London, UK, 1935.

Décobert, C.: Maréotide médiévale. Des Bédouins et des chrétiens, Alexandrie Médiévale, 2, 139-148, 2002 (in French).

Dzierzbicka, D.: Oinos, Production and import of wine in Graecoroman Egypt, JJP Suppl. 31, University of Warsaw, Warsaw, Poland, 2018.

El-Asmar, H. M. and Wood, P.: Quaternary shoreline development: the northwestern coast of Egypt, Quaternary Sci. Rev., 19, 11371149, https://doi.org/10.1016/S0277-3791(99)00097-9, 2000.

El-Falaki, M. B.: Carte des environs d'Alexandrie, available at: https://gallica.bnf.fr/ark:/12148/btv1b10101071m (last access: 22 January 2021), Erhard, Paris, France, 1866

El-Falaki, M. B.: Mémoire sur l'antique Alexandrie, Bianco-Luno, F.-S. Mulhe, Copenhague, Denmark, 1872 (in French).

Embabi, N. S.: The geomorphology of Egypt: landforms and evolution, 1st Ed., Egyptian Geographical Society, Cairo, Egypt, 2004.
Empereur, J.-Y.: New data concerning the foundation of Alexandria, in: Hellenistic Alexandria, edited by: Zerefos, C. and Vardinoyannis, M., Archaeopress, Athens, Greece, 3-12, 2018.

Empereur, J.-Y. and Picon, M.: Les ateliers d'amphores du lac Mariout, Bulletin de Correspondance Hellénique, 33, 75-79, 1998 (in French).

Flaux, C.: Connexion de la région lagunaire d'Alexandrie au Nil depuis 2000 ans: entre contrôle anthropique et forçage naturel, Méditerranée, 117, 73-79, https://doi.org/10.4000/mediterranee.5935, 2011 (in French).

Flaux, C.: Paléo-environnements littoraux Holocène du lac Maryut, nord-ouest du delta du Nil, Égypte, PhD thesis, Aix-Marseille, France, 2012 (in French).

Flaux, C., Morhange, C., Marriner, N., and Rouchy, J.-M.: Bilan hydrologique et biosédimentaire de la lagune du Maryût (delta du Nil, Egypte) entre 8000 et 3200 ans cal. B.P., Geomorphologie, 17, 261-278, https://doi.org/10.4000/geomorphologie.9474, 2011.

Fraser, P.M.: Ptolemaic Alexandria, Clarendon Press, Oxford, UK, 1972.

Flaux, C., El-Assal, M., Marriner, N., Morhange, C., Rouchy, J.-M., Soulié-Märsche, I., and Torab, M.: Environmental changes in the Maryut lagoon (northwestern Nile delta) during the last $\sim 2000$ years, J. Archaeol. Sci., 39, 3493-3504, https://doi.org/10.1016/j.jas.2012.06.010, 2012.

Hairy, I. and Sennoune, O.: Le canal d'Alexandrie: la course au Nil, in Du Nil à Alexandrie: Histoire d'eaux, edited by: Hairy, I., Harpocrates Publishing, Alexandria, Egypt, 2009.

Jacotin, P.: Carte topographique de l'Égypte et de plusieurs parties des pays limitrophes, available at: https://gallica.bnf.fr/ark: /12148/btv1b531569998/f42.item (last access: 22 January 2021), Dépôt général de la Guerre, Paris, France, 1818.

Jacotin, P.: Mémoire sur la construction de la carte de l'Egypte, available at: https://gallica.bnf.fr/ark:/12148/bpt6k280140.r= descriptionel' egypte (last access: 22 January 2021), in: Description de l'Egypte, 17, 437-652, C.L.F. Pancoucke, Paris, France, 1824 (in French).

Le Père, G.: Nome Maréotique, in: Dictionnaire des Découvertes, available at: https://gallica.bnf.fr/ark:/12148/bpt6k2991761/f9. item.r=dictionnaire $\% 20 \mathrm{des} \% 20 \mathrm{~d} \% \mathrm{C} 3 \%$ A 9 couvertes $\% 20 \mathrm{mou} \%$ 20-\%20pat (last access: 22 January 2021), 12, Louis Colas, Paris, France, 214-222, 1823 (in French).

Le Père, G.: Extrait d'un Mémoire sur les lacs et les déserts de la Basse Egypte, available at: https://gallica.bnf.fr/ark:/12148/ bpt6k28013n.r=descriptiondel' egypte (last access: 22 January 2021), in: Description de l'Egypte, 16, 199-227, Panckoucke, Paris, France, 1825 (in French).

Le Père, G.: Mémoire sur la partie occidentale de la province de Bahyreh, connue anciennement sous le nom de nome maréotique, available at: https://gallica.bnf.fr/ark: /12148/bpt6k28016p/f1.item.r=descriptiondel' egypte (last access: 22 January 2021), in: Description de l'Egypte, 18, 29-57, Panckoucke, Paris, France, 1829 (in French).

Linant de Bellefonds, L. M. A.: Mémoires sur les principaux travaux d'utilité publique exécutés en Egypte, available at: https://books.google.de/books?id=tepYAAAAYAAJ\& printsec $=$ frontcover $\& \mathrm{hl}=\mathrm{fr} \# \mathrm{v}=$ onepage $\& \mathrm{q} \& \mathrm{f}=$ false (last access: 22 January 2021), Arthus Bertrand, Paris, France, 1873 (in French). 
Macklin, M. G., Toonen, W. H. J., Woodward, J. C., Williams, M. A. J., Flaux, C., Marriner, N., Nicoll, K., Verstraeten, G., Spencer, N., and Welsby, D.: A new model of river dynamics, hydroclimatic change and human settlement in the Nile Valley derived from meta-analysis of the Holocene fluvial archive, Quaternary Sci. Rev., 130, 109123, https://doi.org/10.1016/j.quascirev.2015.09.024, 2015.

Nenna, M. D., Simony, A., Machinek, K., Soukiassian, G., Pichot, V., Awad, I., Séguier, R., Abdelaziz, M., Elsayed, M., Hairy, I., and Soubias, P.: Alexandrie (actions du Centre d'études alexandrines), Bulletin archéologique des Écoles françaises à l'étranger, Égypte, https://doi.org/10.4000/baefe.1094, 2020 (in French).

Oliver, F. W.: Dust-Storms in Egypt and Their Relation to the War Period, as Noted in Maryut, 1939-45, Geogr. J., 106, 26, https://doi.org/10.2307/1790101, 1945.

Pennington, B. T., Sturt, F., Wilson, P., Rowland, J., and Brown, A. G.: The fluvial evolution of the Holocene Nile Delta, Quaternary Sci. Rev., 170, 212-231, https://doi.org/10.1016/j.quascirev.2017.06.017, 2017.

Pichot, V.: La Maréotide: région fertile de la chôra d'Alexandrie, carrefour du commerce, in Quartiers artisanaux en Grèce ancienne, Une perspective méditerranéenne, edited by Esposito, A. and Sanidas, G., Presses Universitaires du Septentrion, Lille, France, 81-104, 2012 (in French).

Pichot, V. and Flaux, C.: Les fours à amphores du Haut-Empire du site d'Akadémia (Maréotide): campagne de fouille et carottages 2014, BCE 25, 259-276, 2015 (in French).

Pichot, V. and Simony, A.: An archaeological map of the Mareotid: initial results regarding the evolution of occupation in the region, in: Western borders and margins of Egypt from Antiquity to the Middle Ages, edited by: Boussac, M.-F., Dhennin, S., Redon, B., Somaglino, C., and Tallet, G., IFAO press, in press, 2021.

Reclus, E.: L'Afrique Septentrionale. Le Bassin du Nil, Hachette et cie, Paris, France, 1885 (in French).

Redon, B., Vanpeene, M., and Pesenti, M.: "La vigne a été inventée dans la ville égyptienne de Plinthine". À propos de la découverte d'un fouloir saïte à Kôm el-Nogous (Maréotide), Bulletin de l'Institut français d'archéologie orientale, 116, 303-323, https://doi.org/10.4000/bifao.440, 2017 (in French).

Rennell, J.: The Geographical System of Herodotus, available at: https://archive.org/details/geographicalsys00renn/page/ n7/mode/2up (last access: 22 January 2021), W. Bulmer, London, UK, 1800.

Sennoune, O.: Alexandrie dans les récits de voyage, VIe-XVIIIe siècles, L'Harmattan, Paris, France, 2015 (in French).
Stanley, J.-D.: Nile delta margin: failed and fluidized deposits concentrated along distributary channels / La marge du delta du Nil: concentration de dépôts fracturés et fluidisés le long des paléochenaux fluviatiles, Geomorphology, 9, 211-226, https://doi.org/10.3406/morfo.2003.1186, 2003.

Stanley, J.-D., Goddio, F., and Schnepp, G.: Nile flooding sank two ancient cities, Nature, 412, 293-294, https://doi.org/10.1038/35085628, 2001.

St John, B.: Adventures in the Libyan Desert, available at: https: //archive.org/details/adventuresinliby00stjo/page/n7/mode/2up (last access: 22 January 2021), Putnam-John Murray, New York-London, 1849.

St John, B.: Map to Illustrate a Journey from Alexandria (Egypt) to The Oasis of Siwah, available at: https://gallica.bnf.fr/ark: /12148/btv1b53136219p/ (last access: 22 January 2021) Housselin, Paris, France, 1850.

Strabo: Géographie, Livre XVII, 1re partie: l'Égypte et l'Éthiopie nilotique, text edited and translated by Laudenbach, B., Les Belles Lettres, Paris, France, 2015.

Survey of Egypt: Mudiriyet El-Beheira, available at: https://www.davidrumsey.com/luna/servlet/detail/ RUMSEY 8 1 317305 90086593:Sheet-47-Bahig (last access: 22 January 2021), Sheet of the 1:50,000 series, Bahîg V-VI N.W., 1910.

Tronchère, H.: Approche paléoenvironnementale de deux sites archéologiques dans le delta du Nil: Avaris et la branche Pélusiaque, Taposiris et le lac Mariout, $\mathrm{PhD}$ thesis, Lumière Lyon 2, Lyon, France, 2010 (in French).

Tronchère, H., Millet, B., Goiran, J.-P., Carbonel, P., Djerbi, H., Vera, R., Torab, M., Elassal, M., and Callot, Y.: Geoarchaeological results from the harbor of Taposiris and implications concerning the construction of the harbor, AEundL, 22-23, 383-394, https://doi.org/10.1553/s383, 2014.

Tsoar, H. and Pye, K.: Dust transport and the question of desert loess formation, Sedimentology, 34, 139-153, https://doi.org/10.1111/j.1365-3091.1987.tb00566.x, 1987.

US Geological Survey (USGS): EarthExplorer, available at: https: //earthexplorer.usgs.gov/, last access: 22 January 2021.

Warne, A. and Stanley, J.-D.: Late Quaternary Evolution of the Northwest Nile Delta and Adjacent Coast in the Alexandria Region, Egypt, J. Coastal Res., 9, 26-64, 1993.

Woronko, B.: Late-Holocene dust accumulation within the ancient town of Marea (coastal zone of the South Mediterranean Sea, N Egypt), Quaternary Int., 266, 4-13, https://doi.org/10.1016/j.quaint.2011.09.010, 2012. 